ISSN Cetak \& Online : 2355-5831/ 2355-9934

\title{
PROSES PENERBITAN SERTIPIKAT HAK ATAS TANAH
}

\author{
Suryaningsih $^{(1)}$ \\ Zainuri ${ }^{(2)}$ \\ (1) Dosen Fakultas Hukum Wisnuwardhana Malang \\ (2) Dosen Fakultas Hukum Universitas Wiraraja \\ surya.nings@yahoo.com ${ }^{(1)}$ \\ zainuri@wiraraja.ac.id ${ }^{(2)}$
}

\begin{abstract}
ABSTRAK
Pentingnya peranan sertipikat, kekuatan pembuktiannya tidak hanya berlaku eksternal/terhadap pihak luar, tetapi juga mempunyai kekuatan internal, yakni pemberian rasa aman bagi para pemegang/pemiliknya, serta para ahli warisnya agar dikemudian hari ahli warisnya tidak mengalami kesulitan. Sertipikat diberikan bagi tanah - tanah yang ada surat ukurnya, ataupun tanah - tanah yang sudah diselenggarakan pengukuran desa demi desa, oleh karenanya sertipikat ini merupakan suatu pembuktian yang kuat, baik subyek maupun obyek hak atas tanah. Sehubungan dengan pentingnya peranan sertipikat tanah maka, Pasal 19 Undang Undang nomor 5 tahun 1960 tentang Peraturan Dasar Pokok Pokok Agraria yang disebut dengan UUPA, memerintahkan untuk diadakannya suatu perbuatan yaitu pendaftaran tanah yang merupakan realisasi dari salah satu tujuan UUPA yang output-nya adalah surat tanda bukti hak yang dinamakan sertipikat.
\end{abstract}

Kata Kunci : Penerbitan, Sertipikat, Hak-Hak Atas Tanah 


\section{A. PENDAHULUAN}

Hubungan tanah dengan manusia adalah sangat erat, dimana tanah sebagai benda tetap akan selalu utuh dan akan abadi yang tidak akan musnah di permukaan bumi kecuali adanya hari akhir.

Tanah memiliki fungsi dan kedudukan yang sangat penting dalam berbagai kehidupan, terlebih lagi sebagai tempat bermukim atau perumahan. Maraknya pembangunan di berbagai bidang kehidupan menyebabkan tanah menjadi komoditiyang mempunyai nilai ekonomi yang sangat tinggi dan sulit dikendalikan. (Adrian Sutedi, 2009, 22)

Kondisi tersebut akan mengakibatkan meningkatnya kebutuhan akan tanah, sehingga perlu adanya kepastian hukum dan kepastian hak atas tanah yang dipunyainya.

Sehubung hal tersebut diatas, Pasal 19 Undang Undang nomor 5 tahun 1960 tentang Peraturan Dasar Pokok Pokok Agraria yang disebut dengan UUPA, memerintahkan untuk diadakannya suatu perbuatan yaitu pendaftaran tanah yang merupakan realisasi dari salah satu tujuan UUPA yang output-nya adalah surat tanda bukti hak yang dinamakan sertipikat.

Pendaftaran tanah berarti mencatatkan hak-hak (HM, HGU, HGB, H Pakai atas tanah Negara) yang dipegang oleh perorangan atau kelompok, ataupun suatu lembaga atas sebidang tanah yang kemudian oleh Negara melalui pejabat yang berwenang dikeluarkan surat tanda bukti kepemilikan hak yaitu sertipikat.

Hak-hak ini bermacam-macam, antara lain Hak Milik, Hak Guna Bangunan (HGB), Hak Guna Usaha (HGU), Hak Pakai Atas Tanah Negara dan lain lain. UUPA memerintahkan diadakannya pendaftaran tanah dalam rangka menjamin kepastian hukum dan kepastian hak atas tanah sesuai isi Pasal 19.

Adapun tujuan pendaftaran tanah menurt Pasal 3 Peraturan Pemerintah Nomor 24 tahuin 1997, antar lain :

1. Untuk memberikan kepastian hukum dan perlindungan hukum kepada pemegang hak atas suatu bidang tanah, satuan rumah susun dan hakhak lain, agar dengan mudah dapat membuktikan bahwa dirinyalah 


\section{IURNAL JENDELA HUKUM}

ISSN Cetak E Online : 2355-5831/ 2355-9934

sebagai pemegang hak atas tanah yang bersangkutan.

2. Untuk menyediakan informasi kepada pihak-pihak yang berkepentingan termasuk pemerintah agar dengan mudah dapat memperoleh data yang diperlukan dalam mengadakan perbuatan hukum mengenai bidang-bidang tanah dan satuan-satuan rumah susun yang sudah terdaftar.

3. Untuk terselenggaranya tertib administrasi pertanahan.

Sebagai akibat adanya perbuatan hukum pendaftaran hak atas tanah adalah adanya sertipikat tanah yang merupakan salinan buku tanah dan salinan surat ukur yang dijilid menjadi satu dan diberi sampul yang bentuknya ditetapkan oleh Peraturan Pemerintah. (Bachtiar Effendi: 1993: 25)

Dengan adanya sertipikat, maka akan memberikan kekuatan pembuktian bagi orang yang tercantum namanya dalam sertipikat tersebut manakala suatu ketika terjadi sengketa tanah tersebut di pengadilan. (Benny Bonsu; 1997; 125).

\section{B. PEMBAHASAN}

\section{Pengertian Sertipikat}

Di dalam Hukum Agraria, pengertian sertipikat pada dasarnya adalah merupakan abstraksi dari daftar umum hak atas tanah dan merupakan satu-satunya pembuktian formal adanya hak atas tanah, atau dengan kata lain dapat dikatakan bahwa sertipikat merupakan turunan atau salinan dari buku tanah dan surat ukur. (Benny Bonsu: 1997; 1).

Sesuai dengan Peraturan Pemerintah nomor 10 tahun 1961 tentang Pendaftaran Tanah, maka yang dimaksud dengan:

"Sertipikat adalah Surat Tanda Bukti Hak yang terdiri dari Salinan Buku Tanah dan Surat Ukur yang diberi sampul dan dijilid menjadi satu, yang bentuknya ditetapkan oleh Menteri Negara Agraria atau Kepala Badan pertanahan Nasional".

Sertipikat diberikan bagi tanahtanah yang ada surat ukurnya, ataupun tanah-tanah yang sudah diselenggarakan pengukuran desa demi desa, oleh karenanya sertipikat ini merupakan suatu pembuktian yang kuat, baik subyek maupun obyek hak atas tanah. 


\section{IURNAL JENDELA HUKUM}

ISSN Cetak \& Online : 2355-5831/ 2355-9934

Sertipikat tanah adalah salinan buku tanah dan salinan surat ukur yang kemudian dijilid menjadi satu serta diberi sampul yang bentuknya ditetapkan oleh peraturan perundang undangan. Sertipikat tanah yang diberikan tersebut adalah akibat dari adanya perbuatan hukum pendaftaran hak atas tanah sebagaimana yang telah diatur dalam Pasal 1 Peraturan Pemerintah nomor 10 tahun 1961. (Bachtiar Effendie: 1993: 25).

Dalam Pasal 32 ayat (1) Peraturan Pemerintah nomor 24 tahun 1997 tentang Pendaftaran Tanah tertuang bahwa:

"Sertipikat merupakan surat tanda bukti hak yang berlaku sebagai alat pembuktian yang kuat mengenai dat fisik dan data yuridis yang termuat di dalamnya, sepanjang data fisik dan data yuridis tersebut sesuai dengan data yang ada dalam surat ukur dan buku tanah hak yang bersangkutan”.

Dengan adanya pengertian tersebut, berarti sertipikat dinyatakan sebagai alat bukti yang kuat, dalam artian bahwa selama tidak dapat dibuktikan sebaliknya, maka sertipikat tersebut harus diterima sebagai benar. Sudah barang tentu data fisik dan data yuridis yang tercantum dalam sengketa harus sesuai dengan data yang tercantum dalam buku tanah dan surat ukur. (A.P Parlindungan; 1999; 125-126)

Dengan demikian, dalam hal adanya 2 (dua) atau lebih sertipikat tanah yang dijadikan sebagai alat bukti, maka kedua atau lebih sertipikat tersebut haruslah dinilai tiadak mempunyai kekuatan pembuktian yang mutlak. Oleh karenanya, sesuai dengan sistem negatif dalam pendaftaran tanah di Indonesia, yang mana akan dicari bukti - bukti lain untuk menentukan siapakah yang berhak atas tanah tersebut, dus akibatnay salah satu dari 2 (dua) atau lebih sertipikat tanah tersebut akan dinyatakan tidak berlaku /tidak sah menurut hukum berdasarkan keputusan hakim yang memeriksa dan mengadili perkaranya, sampai kemudian mendapatkan putusan hakim yang telah mempunyai kekuatan hukum tetap. Pihak yang menang melalui Kepala Kantor Agraria/ Badan Pertanahan Nasional setempat dapat memohon kepada Menteri dalam Negeri c.q. Direktur Jenderal Agraria Departemen Dalam Negeri RI di Jakarta, untuk meminta pembatalan sertipikat tanah yang dikalahkan itu dengan dilampirkan turunan keputusan 


\section{IURNAL JENDELA HUKUM}

ISSN Cetak \& Online : 2355-5831/ 2355-9934

pengadilan yang mempunyai kekuatan hukum tetap tersebut. (A.P. Parlindungan;1999; 26-27).

$$
\text { Disamping sertipikat }
$$

sebagaimana tersebut di atas, maka masih dikenal apa yang dimaksud dengan "sertipikat sementara", yakni surat tanda bukti hak yang terdiri dari salinan buku tanah dan gambar situasi yang diberi sampul dan dijilid menjadi satu yang bentuknya ditetapkan oleh Menteri Negara Agraria/ Kepala Badan Pertanahan Nasional. Sertipikat sementara ini diberikan bagi tanah-tanah di desa-desa yang belum ada surat ukurnya, dalam artian tanah-tanah di desa-desa yang belum dihitung, gerakan pengukuran desa demi desa dan oleh karenannya sertipikat sementara ini ini merupakan alat pembuktian mengenai macam-macam hak dan siapa yang memilikinya, jadi tidak membuktikan mengenai luas dan batas-batas tanah. (Ahli Achmad Chomzah; 2002; 123124).

Perlu diketahui juga Peraturan Pemerintah Nomor 24 tahun 2007 tidak lagi membedakan antara sertipikat dengan Sertipikat Sementara, juga antara Surat Ukur dan Gambar Situasi. Baik sertipikat maupun sertipikat sementara, keduanya berlaku sebagai alat pembuktian yang kuat, sepanjang tanah yang dimaksud dalam keadaan tidak sengketa, sedangkan khusus untuk sertipikat sementara mempunyai arti penting dan praktis bagi daerah yang belum lengkap.

\section{Kegunaan Sertipikat}

Ketentuan PerUndang-Undangan dan Kebijakan Pemerintah dalam penerbitan sertipikat pada hakekatnya dimaksudkan untuk :

a. Memberikan kepastian hukum mengenai hak-hak atas tanah, baik oleh manusia secara perorangan maupun oleh suatu badan hukum.

b. Memberi bukti otentik bahwa orang yang tercantum namanya dalam sertipikat tersebut adalah pemegang hak sesungguhnya.

c. Memberi kepastian mengenai subyek dan obyek hak atas tanah, serta status hak atas tanah tersebut.

Singkatnya dengan adanya sertipikat maka akan memberikan kekuatan pembuktian bagi orang yang tercantum namanya dalam sertipikat tersebut manakala suatu ketika terjadi sengketa perdata di persidangan Pengadilan Negeri. 


\section{IURNAL JENDELA HUKUM}

ISSN Cetak \& Online : 2355-5831/ 2355-9934

Fungsi penerbitan sertipikat hak atas tanah adalah jelas sebagai pegangan bagi pemilik akan bukti-bukti haknya yang tertulis, kecuali masih ada catatan pada buku tanah, maka sertipikat tidak dapat diterbitkan. Hal ini tercantum dalam Pasal 31 Peraturan Pemerintah Nomor 24 Tahun 1997 sebagai berikut:

- Ayat 1: Sertipikat diterbitkan untuk kepentingan pemegang hak yang bersangkutan sesuai dengan data fisik dan data yuridis yang telah di daftar dalam buku tanah sebagaimana dimaksud dalam Pasal 30 ayat (1).

- Ayat 2: Jika di dalam buku tanah terdapat catatan sebagaimana dimaksud dalam Pasal 30 ayat (1) huruf $b$ yang menyangkut data yuridis, atau catatan sebagaimana dimaksud dalam Pasal 30 ayat (1) huruf c, d, dan e yang menyangkut data fisik dan data yuridis penerbitan sertipikat ditangguhkan sampai catatan yang bersangkutan di hapus.

- Ayat 3: Sertipikat hanya boleh diserahkan kepada pihak yang namanya tercantum dalam buku tanah yang bersangkutan sebagai pemegang hak atau kepada pihak lain yang dikuasakan olehnya.
Adapun sertipikat tanah adalah dikeluarkan oleh Direktorat Jendral Agraria Departemen Dalam Negeri Republik Indonesia c.q. Kepala Kantor Agraria Kota/Kabupaten atas nama Walikota atau Bupati Kepala Daerah Tingkat II setempat. Dengan demikian berarti bahwa pencabutan/ pembatalannyapun harus melalui Instansi Agraria pula. (Benny Bosu; 1997; 3) Mahkamah Agung Republik Indonesia melalui keputusannya tanggal 5 September 1973 Nomor regristasi 716K/Sip/1973 dalam kaidah hukumnya menyebutkan bahwa pengeluaran/pencabutan dan pembatalan surat sertipikat adalah semata-mata wewenang dari Kantor Pendaftran dan pengawasan Pendaftaran Tanah, bukan termasuk wewenang Pengadilan Negeri, maka gugatan penggungat-penggugat mengenai pencabutan sertipikat tidak dapat diterima.

Adanya sertipikat juga akan menambah kepercayaan masyarakat dalam lalulintas hukum, misalnya dalam hal jual beli, tukar menukar, dan lainlain. Disamping itu sertipikat dapat menambah nilai jual suatu hak atas tanah apabila dibandingkan dengan pembelian tanah hanya didasarkan pada bukti-bukti 


\section{IURNAL JENDELA HUKUM}

ISSN Cetak \& Online : 2355-5831/ 2355-9934

lainnya, seperti pipil, petok D, akta jual beli, PPAT, dan sebaginya. Hal ini masih bisa dimaklumi mengingat surat yang disebutkan terakhir masih perlu ditingkatkan pengurusannnya, yang notabene banyak mengeluarkan dana dan memakan waktu yang lama.

Mengingat demikian penting nya peranan sertipikat, kekuatan pembuktiannya tidak hanya berlaku eksternal/ terhadap pihak luar, tetapi juga mempunyai kekuatan internal, yakni pemberian rasa aman bagi para pemegang/pemiliknya, serta para ahli warisnya agar dikemudian hari ahli warisnya tidak mengalami kesulitan.

Keberadaan sertipikat tidak hanya mempunyai aspek/ nilai ekonomi dan hukum, tetapi juga mengandung aspek/ nilai sosial, dalam artian bahwa walaupun seseorang memiliki sertipikat atas suatu persil yang luasnya sesuai dengan batas-batas yang ditentukan, namun manakala kepentingan sosial/ umum memerlukan sebagian atau seluruh tanah/persil tersebut, maka pemegang sertifikat tersebut wajib mengikhlaskan haknya demi kepentingan soaial/umum, mungkin harga tanah/persil tersebut jauh dari ahrga pasaran umum. Dengan demikian, luas tanah dalam sertipikat tersebut terpaksa dikurangi/disesuaikan dengan keadaan terakhir setelah diambil (untuk kepentingan sosial/umum tersebut). Hal ini sesuai dengan jiwa dan semangat yang terdapat dalam Undang Undang Nomor 5 Tahun 1960 tentang Peraturan Dasar Pokok-Pokok Agraria, yang pada hakekatnya menentukan bahwa Hak Milik (HM), Hak Guna Usaha (HGU), Hak Guna Bangunan (HGB), Hak Pengelolaan dan Hak Pakai mempunyai fungsi sosial.

\section{Proses Penerbitan Sertipikat}

Dalam menyelengarakan pendaftaran tanah untuk pertama kali menurut Peraturan Pemerintah Nomor 24 Tahun 1997 Pasal 1 ayat (10) dan (11), secara tegas dibedakan antara penyelenggaraan pendaftaran tanah secara sistematik dan pendaftaran tanah secara sporadik. Baik pendaftaran secara sistematik maupun secara maupun secara sporadik terhadap pengukuran bidangbidang tanahnya, diterbitkan Surat Ukur (tidak lagi menggunakan istilah "Gambar Situasi"). Kedua macam pengukuran ini hendaknya tetap memenuhi kaidah-kaidah teknis prngukuran dan pemetaan, sehingga bidang tanah yang diukur dapat 


\section{IURNAL JENDELA HUKUM}

ISSN Cetak \& Online : 2355-5831/ 2355-9934

dipetakan dan dapat diketahui letak serta batasnya di atas peta, juga dapat direkontruksi batas-batasnya di lapangan.

Dalam Peraturan Pemerintah Nomor 24 Tahun 1997 tidak dibedakan lagi antara sertipikat dan sertipikat sementara, juga antara surat ukur dan gambar situasi. Dengan demikian, pada pendaftaran tanah secara sistematik dan sporadik hanya terdapat satu istilah yaitu "Sertipikat" tidak ada lagi istilah "Sertipikat Sementara".

Pendaftaran tanah secara sistematik menurut Peraturan Menteri Agraria/ Kepala Badan pertanahan Nasional Nomor 3 Tahun 1997 Pasal 46 ayat (3) meliputi wilayah satu desa/kelurahan yang lokasinya ditetapkan oleh pemerintah, dalam hal ini adalah Menteri Dalam Negeri atas usulan Kepala Kantor Wilayah Pertanahan yang didasarkan atas rencana kerja Kantor Pertanahan, dengan kriteria daerah/ wilayah sebagai berikut:

a. Sebagian wilayahnya sudah terdaftar secara sistematik;

b. Jumlah bidang tanah yang terdaftar relatif kecil, yakni berkisar sampai dengan $30 \%$ dari perkiraan jumlah bidang tanah yang ada; c. Merupakan daerah pengembangan perkotaan yang tingkat pembangunannya tinggi;

d. Merupakan daerah pertanian produktif;

e. Tersedia titik-titik ke angka dasar teknik nasional.

Pendaftaran tanah secara sistematik dibiayai oleh anggaran Pemerintah Pusat atau Pemerintah Daerah, atau secara swadaya oleh masyarakat dengan persetujuan Menteri Dalam Negeri yang dalam pelaksanaan pendaftaran tanah tersebut, Kantor Badan Pertanahan dibantu Panitia Ajudikasi yang dibentuk oleh Menteri atau Pejabat yang ditunjuk.

Menurut Peraturan Menteri Agraria/ Kepala Kantor Pertanahan Nomor 3 Tahun 1997 Pasal 50 ayat (1) dan (2), Panitia Ajudikasi terdiri atas :

a. Ketua merangkap anggota, dijabat oleh Pegawai Kantor Pertanahan yang mempunyai kemampuan pengetahuan dibidang pendaftaran tanah atau hak-hak atas tanah, dan pangkatnya yang tertinggi diantara para anggota;

b. Wakil Ketua I dan Wakil Ketua II masing-masing merangkap anggota, dijabat pegawai Kantor Pertanahan 


\section{IURNAL JENDELA HUKUM}

ISSN Cetak E Online : 2355-5831/ 2355-9934

yang mempunyai kemampuan dan pengetahuan di bidang pendaftaran tanah dan hak-hak atas tanah;

c. Kepala Desa/Kepala Kelurahan yang bersangkutan atau Pamong Desa yang ditunjuk sebagai anggota;

d. Keanggotaan Panitia Ajudikasi dapat ditambah satu orang dari tetua Adat, Kepala Dusun atau kepala Lingkup yang mengetahui dengan benar riwayat di lokasi pendaftaran tanah secara sistematik.

Menurut Pasal 51 Peraturan Menteri Agraria/ Kepala Kantor Pertanahan Nomor 3 Tahun 1997, "Panitia Ajudikiasi dalam melaksanakan tugasnya dibantu oleh satuan tugas pengukuran dan pemetaan yang terdiri dari beberapa petugas ukur, sa tuan tugas pengumpulan data yuridis yang terdiri dua orang pegawai Kantor Pertanahan yang masing-masing mempunyai pengetahuan di bidang pendaftaran tanah dan hak-hak atas tanah"

Sedangkan pendaftaran tanah secara sparodik meliputi bidang-bidang atas permintaan pemegang atau penerima hak yang bersangkutan secara individual ataupun dapat juga secara massal. Pendaftaran tanah secara sparodik maupun secara sistematik untuk pertama kali menurut peraturan Pemerintah Nomor 24 tahun 1997 pasal 12 meliputi kegiatan-kegiatan sebagai berikut :

a. Pengumpulan dan pengolahan data fisik;

b. Pembuktian hak dan pembukuannya;

c. Penerbitan sertifikat;

d. Penyajian data fisik dan data yuridis;

e. Penyimpanan daftar umum dan dokumen.

Proses penerbitan sertipikat menurut peraturan pemerintah Nomor 24 Tahun 1997 dapat digambarkan melalui skema sebagai berikut :

\section{Proses Penerbitan Sertipikat}

Kegiatan pelaksanaan atau implementasi pendaftaran tanah dan proses penerbitan sertipikat menurut Peraturan Pemerintah Nomor 24 tahun 1997 dapat digambarkan dengan skema sebagai berikut : 


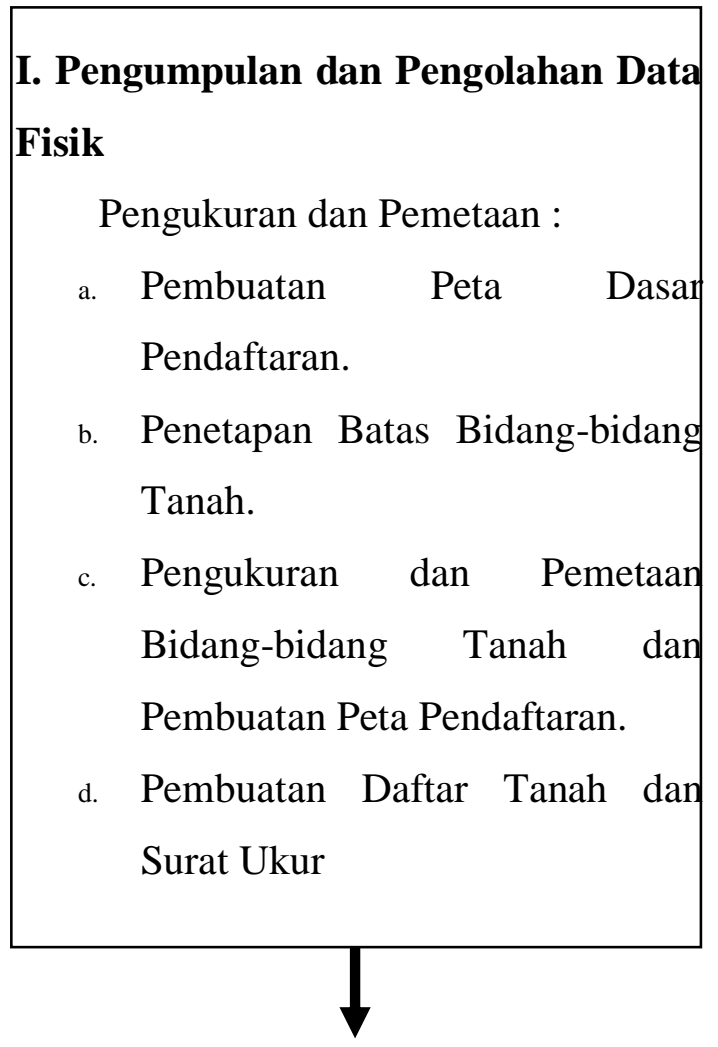

II. Pengumpulan dan Pengolahan Data Yuridis

e. Pengumuman Data Fisik dan Data Yuridis

f. Pengesahan Data Fisik dan data Yuridis

g. Pembuktian Hak atas Tanah

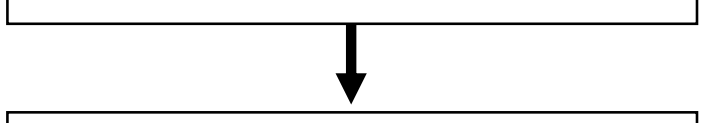

\section{Penerbitan Sertipikat}

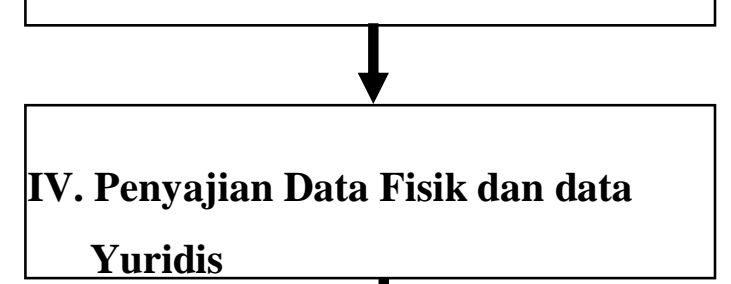
Yuridis

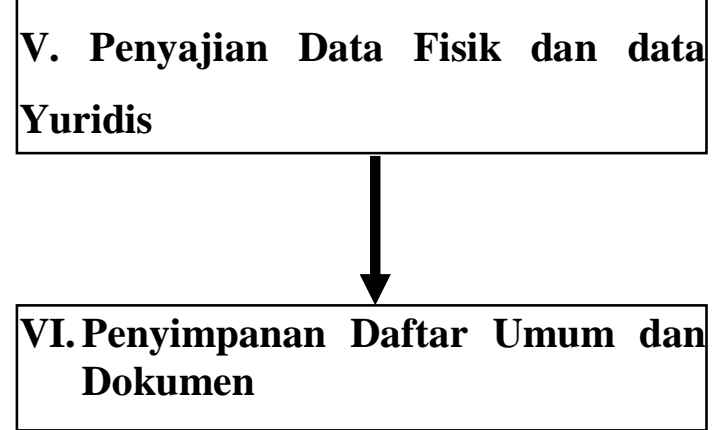

Proses Penerbitan sertipikat diatas melalui prosedur yang sudah ditetapkan dengan Peraturan Pemerintah Nomor 24 Tahun 1997 tentang Pendaftaran Tanah. Yang mana penerbitan sertipikat dimaksud agar pemegang dapat dengan mudah membuktikan haknya. Oleh karena itu sertipikat merupakan alat pembuktian yang kuat, sebagaimana dinyatakan dalam pasal 19 UUPA. Sehubung dengan itu apabila masih ada ketidakpastian mengenai hak atas tanah yang bersangkutan, yang ternyata masih adanya catatan dalam pembukuannya, pada prinsipnya sertipikat belum dapat diterbitkan. Namun apabila catatan tersebut hanya mengenai data fisik yang belum lengkap, tetapi tidak disengketakan, maka sertipikat dapat diterbitkan. 


\section{IURNAL JENDELA HUKUM}

ISSN Cetak E Online : 2355-5831/ 2355-9934

\section{KESIMPULAN}

Dari pembahasan diatas, dapat diketahui bagaimana proses penerbitan sertipikat atas tanah dan pentingnya sertipikat atas tanah untuk pemilik hak atas tanah. Ketentuan PerUndangUndangan dan Kebijakan Pemerintah dalam penerbitan sertipikat pada hakekatnya dimaksudkan untuk memberikan kepastian hukum mengenai hak-hak atas tanah, baik oleh manusia secara perorangan maupun oleh suatu badan hukum, memberi bukti otentik bahwa orang yang tercantum namanya dalam sertipikat tersebut adalah pemegang hak sesungguhnya, memberi kepastian mengenai subyek dan obyek hak atas tanah, serta status hak atas tanah tersebut.

Singkatnya dengan adanya sertipikat maka akan memberikan kekuatan pembuktian bagi orang yang tercantum namanya dalam sertipikat tersebut manakala suatu ketika terjadi sengketa perdata di persidangan Pengadilan Negeri.

Adanya sertipikat juga akan menambah kepercayaan masyarakat dalam lalulintas hukum, misalnya dalam hal jual beli, tukar menukar, dan lainlain. Disamping itu sertipikat dapat menambah nilai jual suatu hak atas tanah apabila dibandingkan dengan pembelian tanah hanya didasarkan pada bukti-bukti lainnya, seperti pipil, petok D, akta jual beli, PPAT, dan sebagainya.

Dengan melihat pentingnya sertipikat tanah bagi pemilik hak atas tanah maka bagi pemilik hak atas tanah yang belum memiliki sertipikat dianjurkan untuk segera mengurus sertipikat sebagai bukti kepemilikan.

\section{DAFTAR BACAAN}

\section{Buku}

Bonsu, Benny, 1997. Perkembangan Terbaru Sertipikat (Tanah, Tanggungan, dan Condominium), Jakarta ; mediatama Saptakarya.

Chomzah, Ali, Acmad, 2002. Hukum Pertanahan II Sertipikat dan Pernasalahannya. Jakarta ; Prestasi Pustaka.

Effendi, Bachtiar, 1993. Kumpulan Tulisan tentang Hukum Tanah, Bandung: Alumni.

Parlindungan. A.P., 1999. Pendaftaran Tanah di Indonesia, Bandung, Mandar Maju.

Sutedi, Adrian, 2009, Peralihan Hak atas Tanah dan Peralihannya, Sinar Grafika, Jakarta. 


\section{JURNAL JENDELA HUKUM}

ISSN Cetak \& Online : 2355-5831/ 2355-9934

\section{Peraturan Perundang-Undangan}

Undang Undang Nomor 5 Tahun 1960 tentang Peraturan Dasar Pokokpokok Agraria.

Peraturan pemerintah Nomor 24 Tahun 1997 tentang Pendaftaran Tanah.

Peraturan Menteri Negara Agraria/Kepala Badan Pertanahan Nasional Nomor 3 Tahun 1997 tentang Pendaftaran tanah. 